TTR

Traduction, terminologie, rédaction

\title{
Official Language Minority Communities, Machine Translation, and Translator Education: Reflections on the Status Quo and Considerations for the Future \\ Les communautés minoritaires de langue officielle, la traduction automatique et la formation des traducteurs : réflexions sur le statu quo et perspectives
}

\section{Lynne Bowker}

Volume 21, numéro 2, 2e semestre 2008

La formation en traduction : pédagogie, docimologie et technologie II Translator Training: Pedagogy, Evaluation, and Technologies II

URI : https://id.erudit.org/iderudit/037491ar

DOI : https://doi.org/10.7202/037491ar

Aller au sommaire du numéro

Éditeur(s)

Association canadienne de traductologie

ISSN

0835-8443 (imprimé)

1708-2188 (numérique)

Découvrir la revue

Citer cet article

Bowker, L. (2008). Official Language Minority Communities, Machine Translation, and Translator Education: Reflections on the Status Quo and Considerations for the Future. TTR, 21(2), 15-61.

https://doi.org/10.7202/037491ar
Résumé de l'article

En raison principalement de pressions budgétaires, un grand nombre des besoins de traduction des communautés de langue officielle en situation minoritaire au Canada reste à combler. L'utilisation de la traduction automatique pourrait représenter une solution rentable, mais seulement si les membres de cette communauté acceptent cette forme de traduction. Le présent article fait état d'une expérience au cours de laquelle des membres d'une des communautés de langue officielle en situation minoritaire - en l'occurrence les Fransaskois - ont répondu à un sondage visant à mesurer leur opinion de la traduction automatique. Les résultats montrent que, bien que beaucoup de Fransaskois soient réceptifs à l'utilisation de traductions automatiques révisées, les professionnels de la langue s'opposent fermement à l'utilisation de traductions automatiques, sous quelque forme que ce soit. Ce constat porte à se demander si la formation des traducteurs à l'utilisation des outils informatiques pourrait être un facteur sous-jacent à cette réaction à l'utilisation de la traduction automatique, ce qui, en revanche, nous porte à proposer une nouvelle approche visant à mieux intégrer la technologie aux programmes de formation de traducteurs.
Tous droits réservés (c) TTR: traduction, terminologie, rédaction — Les auteurs, 2009
Ce document est protégé par la loi sur le droit d'auteur. L’utilisation des services d'Érudit (y compris la reproduction) est assujettie à sa politique d'utilisation que vous pouvez consulter en ligne.

https://apropos.erudit.org/fr/usagers/politique-dutilisation/ 


\section{Official Language Minority Communities, Machine Translation, and Translator Education: Reflections on the Status Quo and Considerations for the Future}

\section{Lynne Bowker}

\section{Introduction}

It is no secret that the quality of texts that have been translated by a machine translation system is usually inferior to that of texts translated by professional translators. Nevertheless, there are many documented cases of situations where machine translation can fill a genuine need (e.g. Church and Hovy, 1993; Melby, 1997; Gaspari and Hutchins, 2007). To the best of our knowledge, however, there has never been a significant investigation into whether machine translation can meet the needs of Canadians who are living in an official language minority community. This paper reports on such an investigation, the results of which have prompted us to consider a new way of approaching the integration of translation technology into a translator training program.

The paper begins with an overview of what it means to be an official language minority community in Canada, presenting one such community - the Fransaskois - as an example. Next, the question of the cost of providing linguistic support, including translation services, to official language minority communities is examined, and the suggestion made by Canada's Office of 
the Commissioner of Official Languages that an increased use of technology should be considered as a means of meeting the translation needs of these communities is considered. The following section provides an account of an experiment carried out in Saskatchewan where over 100 members of the Fransaskois community were asked to conduct a comparative evaluation of raw machine translation output, edited machine translation output, and human translation in order to determine which type of text was best able to meet their needs. The results of the experiment are discussed, including the interesting observation that of the Fransaskois who participated in this experiment, those who are language professionals reported a very different reaction to machine translation than did those who are not. This prompts, in the final section, a consideration of the way in which translation technology, including machine translation, is taught in translator training programs, which in turn leads into a proposal for a new and more integrated approach to teaching translation technology.

\section{Official Bilingualism and Official Language Minority Communities in Canada}

The country of Canada has two official languages: English and French. These became recognized as the official languages of all federal institutions in Canada following the passage of the Official Languages Act in 1969. In 1988, a new Official Languages Act came into force, which sets out the following three basic objectives of the Government of Canada:

- to ensure respect for English and French as the official languages of Canada and ensure equality of status and equal rights and privileges as to their use in all federal institutions;

- to set out the powers, duties and functions of federal institutions with respect to the official languages of Canada;

- to support the development of English and French linguistic minority communities and generally advance the equality of status and use of the English and French languages within Canadian society.

Additional amendments to the Official Languages Act were passed by the Parliament of Canada in November 2005. Enhancing its 
earlier encouragement, the legislation now requires all federal government agencies to adopt measures to foster the growth of official language minorities and the development of their communities. Designed to promote linguistic duality in Canadian society, these obligations are also now subject to judicial review (Bonin and Kelly, 2008, p. 2).

For the most part, the government has done a reasonable job of meeting the first two objectives. Canadians generally have access to information about federal services in both languages, and they can typically interact with federal institutions in the official language of their choice. ${ }^{1}$ However, it is important to note that the country of Canada is divided into ten provinces and three territories, ${ }^{2}$ with the result that the Canadian federal structure of government is extremely decentralized. Although this decentralization affords flexibility, in the case of official languages, as pointed out by Bourgeois et al. (2007, p. 11), it also brings complexity. Provincial governments have broad responsibilities and they vigorously defend their almost exclusive jurisdiction over areas that, in other countries, would be strongly influenced or controlled by central national authorities. ${ }^{3}$ Therefore, although citizens must communicate with a federal government department to obtain a passport or a Social Insurance Number, for example, there are many other services which fall under the jurisdiction of the provincial governments, such as obtaining a driver's licence, a marriage licence or a birth certificate.

1 As noted by the Office of the Commissioner of Official Languages (OCOL, 2001a), however, there is still room for improvement in providing access to federal government services in both official languages.

2 Note that henceforth, references to "provinces" and "provincial governments" should also be understood to include "territories" and "territorial governments".

3 Some examples of areas that are under federal jurisdiction in Canada include criminal law, national defence, postal service, census, employment insurance, trade regulation, international relations, interprovincial transportation, and citizenship and immigration. Examples of areas that are primarily under provincial jurisdiction include civil rights, natural resources, intra-provincial transportation, healthcare, education, and social welfare. 
Although the federal government can encourage the development and equal treatment of official language minority communities in the provinces, the latter are not legally required to provide provincial services in both official languages. ${ }^{4}$ As a result, for the most part, provincial services are offered only in the language of the majority (i.e., in French within the province of Quebec, and in English outside of Quebec). Understandably, this approach does not sit well with members of the official language minority communities. As part of a cross-Canada consultation exercise conducted by the Office of the Commissioner of Official Languages (OCOL), members of such communities were severe in their judgment of the behaviour of provincial governments with respect to the official languages of Canada (Adam, 2000a, p. 5). ${ }^{5}$ The OCOL went on to criticize the situation, noting "all too often, the federal government transfers its responsibilities to other levels of government, or to the private sector, without ensuring continued respect for the language rights of the persons receiving these services" (Adam, 2001, p. 39) and to observe that "the loss of services in French is more often than not the outcome of such transfers" (Adam, 2000a, p. 7). These observations have since been echoed by the Standing Joint Committee on Official Languages in a report to the Parliament of Canada (SJCOL, 2002, p. 2) and by Lord (2008, p. 16-17) in the Report on the Government of Canada's Consultations on Linguistic Duality and Official Languages.

\subsection{The Fransaskois: A Linguistic Minority Community in Saskatchewan}

In this paper, our focus will be on one particular Canadian official language minority community, namely the Fransaskois, who are Francophones living in the province of Saskatchewan. Located

4 An exception is the province of New Brunswick, whose provincial constitution mandates it to be an officially bilingual province, recognizing both English and French as official languages. However, the remaining Canadian provinces and territories are not constitutionally bilingual.

5 For example, one participant noted that the majority of provincial governments provide so few services in French that French speakers no longer ask for them (ADAM, 2000a, p. 5). 
in the mid-west of Canada, Saskatchewan is the middle of the three prairie provinces, as shown in Figure 1. Typically associated with agriculture, and particularly wheat crops, Saskatchewan also has important forestry, mining (especially potash and uranium), and oil and natural gas industries. Data from Statistics Canada's 2006 census show that the province of Saskatchewan has a total population of 968,157 , with approximately 19,500 inhabitantsroughly $2 \%$ of the total population-having French as a native language. This figure has declined from 1951, when approximately $4.4 \%$ of the residents of Saskatchewan were Francophones (OCOL, 2007, p. 22).

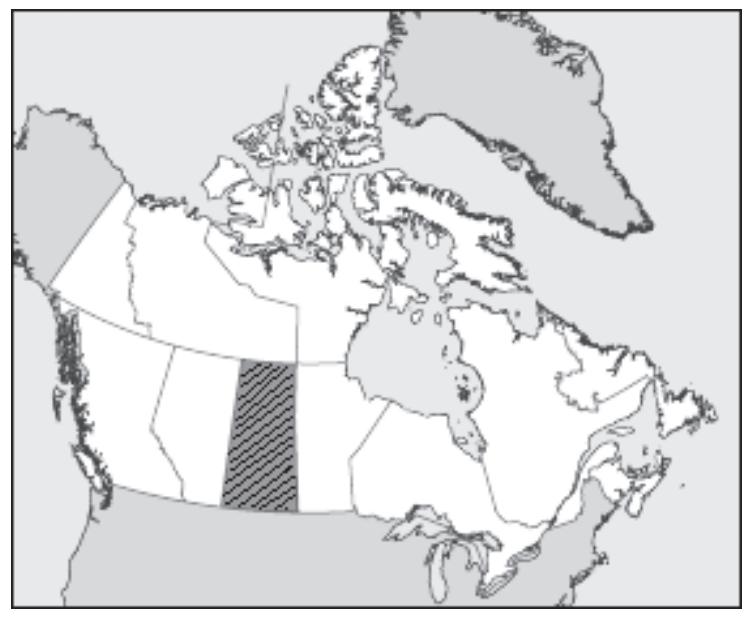

\section{Figure 1. Map showing location of Saskatchewan within Canada.}

Historically, Francophones settled in small rural pockets across Saskatchewan, and according to the OCOL (2007, p. 15), statistics indicate that the majority of Fransaskois still reside in predominantly rural areas. ${ }^{6}$ As noted by Churchill (1998, p. 68), rurally located official language minority communities such as the

6 There is some evidence, however, that in recent decades, owing to the pressures and strains that the changing reality of agricultural economies has imposed on all rural Prairie communities, there has been a trend where people-including Francophones-are moving from rural areas to metropolitan ones in order to find employment (OCOL, 2007, p. 4). 
Fransaskois face particular challenges. Firstly, they are threatened by assimilation, especially if existing levels of federal and/or provincial support for community organizations are reduced. Moreover, provincial governments have proved themselves to be largely reticent when it comes to adopting measures to assist the development of official language minority communities. Churchill (1998, p. 40) notes that in provinces such as Saskatchewan, which have an English-speaking majority and which are also primarily rural, the expansion of public services in French has been driven primarily by legal and constitutional pressures rather than through the political will of the provincial politicians to improve the status of the French language. In Churchill's opinion, a key factor is that the legislatures of these provinces are dominated by rural and small-town politicians who have been particularly resistant to accepting changes to the status quo on social issues of all kinds, not only those dealing with official language policies. Regardless of the specific reason behind the lack of provincial government support for official language minority communities, Francophone residents of Saskatchewan who participated in the OCOL's cross-Canada consultations in 2000 were very clear that this lack of support is keenly felt in their province (Adam, 2000a, p. 114).

Moreover, it would seem that members of the Fransaskois community are also facing an uphill struggle to gain recognition and support outside the political arena. For instance, in 2007, the OCOL sought to discover the perceptions that are held by Anglophones living in Saskatchewan toward French culture and the value of learning French as a second language. The general findings of this investigation included the observation that "The French community in Saskatchewan is not particularly prominent or visible" and that "French culture and heritage in Saskatchewan are in decline" (OCOL, 2007,p. 4). Added to this are the findings of the December 2003 "Survey of Official Languages" conducted by the Centre for Research and Information on Canada. When the results for Saskatchewan are compared to those of other provinces, it appears that Saskatchewan residents show relatively less optimism regarding the value of bilingualism or learning French than do respondents from other provinces. In fact, of all the participants, Saskatchewan respondents seem to attach the 
least importance to learning other languages and valuing French as a language (OCOL, 2007, p. 13). The Fransaskois community is therefore facing a considerable challenge with regard to raising its visibility and promoting the value of its language and culture to the Anglophone majority living in Saskatchewan.

Yet another issue that may be perceived by some as a factor diminishing the importance of French in Saskatchewan is the significant presence of Aboriginal or First Nations language use in the province. The Statistics Canada 2006 census indicates that 141,890 Aboriginal people reside in Saskatchewan, and $36,323(25.6 \%)$ of them have an Aboriginal language as their mother tongue. Moreover, in two of the Canadian territories that border northern Saskatchewan-the Northwest Territories and Nunavut-Aboriginal languages have already been given status as official languages alongside English and French. Although the province of Saskatchewan has not accorded official language status to Aboriginal languages, these nonetheless have a significant presence within the province. As pointed out by Churchill (1998, p. 87), "it is impossible to predict how the concept of First Nations will evolve in law and practice and how this evolution will interact with the concept of official language communities in Canada." However, it is clear that this is an issue that will continue to present challenges to members of both the First Nations and Fransaskois communities in Saskatchewan.

In a somewhat similar vein, members of official language minority communities across Canada, including the Fransaskois, have some concerns about the long-term effects of the rapidly changing demographic composition of the country as an increasing number of immigrants from a wide range of countries come to live in Canada. The 2006 census carried out by Statistics Canada shows that of the total Canadian population, $57.8 \%$ have English as a mother tongue, $22.1 \%$ have French as a mother tongue, and $20.1 \%$ have a mother tongue that is neither English nor French. Moreover, size of the latter group is continuing to increase and has grown from $16.6 \%$ in 1996 . The situation in the province of Saskatchewan is particularly striking: while approximately $2 \%$ of the population is Francophone, more than $12 \%$ report that their mother tongue is not one of Canada's two official languages. As 
noted by Lesage et al. (2008, p. 37), members of official language minority communities are concerned that their status as founding peoples will diminish if their numbers decline in relation to those of other cultures, and that protection granted under the Official Languages Act could be diluted by special measures to promote cultural diversity. Although multiculturalism policies and the Act are not incompatible, members of official language minority communities "increasingly feel like a link in the cultural diversity chain and, as a result, fear losing whatever gains they have achieved under the $A c t$ " (Lesage et al., 2008, p. 37).

\section{Examining the "Cost" of Supporting Official Language Minority Communities}

Although the Fransaskois community is facing a number of challenges, in the opinion of the OCOL, the Saskatchewan provincial government can do a great deal to influence public opinion with regard to language issues:

...the provincial government and its activities can be viewed as being a window through which the general population expresses opinions on various cultures and languages. If government is not taking enough initiatives, then it is likely that the issue is not a priority for a majority of Saskatchewan residents. However, if the provincial government starts a promotion campaign and devotes resources to French, this could initiate discussions in communities about the French language and culture across Saskatchewan. (OCOL, 2007, p. 17)

In their 2007 report, the OCOL suggests that, as a course of action, the Saskatchewan government should make efforts to encourage provincial policy initiatives to promote French language and culture actively in Saskatchewan, and this should include making efforts to create an environment that allows the French language to be used in day-to-day activities (OCOL, 2007, p. 23).

One important way of promoting the use of French in everyday life, as well as raising the profile of the French language in general, could be to increase the critical mass of Frenchlanguage content on provincial and municipal government 
websites in Saskatchewan. This strategy is one that was heavily promoted by former Commissioner of Official Languages Dyane Adam, whose seven-year tenure ran from 1999 to 2006. Throughout her mandate, she made it a priority for the OCOL to encourage the development of French-language resources on the Internet (Adam, 2000b, 2004, 2006; Clavet, 2002; OCOL 1999, 2005). For example, as stated in the 2001 Annual Report of the Office of the Commissioner of Official Languages,

The Commissioner believes that increasing the amount of French on the Internet is a key challenge because the Internet provides a tremendous opportunity to promote the official languages and linguistic duality in Canada. It could also be a valuable tool in supporting the development of official language communities (Adam, 2001, p. 89).

In spite of these efforts, as reported by Lord (2008, p. 14), there nevertheless remains a shortage of French-language material at the disposal of official language minority communities: "the Francophone minority communities point to a lack of relevant Web content in their own language".

One of the principal reasons that provincial and municipal governments are reluctant to provide bilingual websites is because translation can be both costly and time consuming (OCOL, 2005, p. 58; OCOL, 2007, p. 57). As observed by Adam (2005, p. 107), one of the recurring criticisms levelled at bilingualism since the 1960s has been its cost to taxpayers, and Churchill $(1998$, p. 63) emphasizes that if official languages policies are to succeed, their costs must be kept to a reasonable level. Moreover, it is not simply the case of finding a lump sum of money to pay for a one-off translation of existing websites; rather, it requires an ongoing commitment because it is exceedingly difficult for a government to claw back a service once it has been offered, and the web is a dynamic resource that is constantly being updated.

Another oft-cited reason for not translating such websites is that there is a recognized shortage of professional translators in Canada (Clavet, 2002, p. 13; Lord, 2008, p. 15). This is being exacerbated by the fact that many of the country's 
current translators are Baby Boomers who will soon be retiring (CTISC, 1999, p. 79).

Given these circumstances, the challenge of providing bilingual websites is becoming increasingly intractable because, as the popularity of the Internet grows, the volume of documents waiting to be translated continues to grow as well. For example, as noted by the OCOL (2005, p. 27), the advent of the web has given rise to a $15 \%$ increase in the volume of content to be translated since 1996. According to Clavet (2002, p. 13) this number could actually be closer to $25 \%$.

Even as far back as 1999, when the Internet was still a relatively new phenomenon, the OCOL found the lack of resources-both financial and human-to be a systematic obstacle blocking the translation of documents to be posted on the Internet. The OCOL initially suggested that larger budgets are required if the volume of documents to be translated for inclusion on the web is to be increased (OCOL, 1999). However, the OCOL (2005, p. 58) also recognizes that there is not an endless supply of financial and human resources at the disposal of institutions to perform translation, and as a result, these institutions are often faced with difficult choices which usually entail some form of selective translation.

Therefore, in addition to recommending budget increases where possible, the OCOL has also repeatedly suggested that technology should be explored as a partial solution for helping to bridge the gap between supply and demand for translation (Adam,2001, p. 27, 2005, p. 55; Clavet, 2002, p. 52; OCOL, 2005, pp. 58-59). For instance, the OCOL (2005, p. 58) proposes that "the government should also explore new avenues to increase its effectiveness and efficiency in creating, managing, and translating documents. Specifically, it should substantially step up its use of technolinguistic tools and adapt its organizational policies and practices to maximize the impact of its software." This type of strategy has since been echoed by others, such as Lord (2008, pp. 15-16). 
In fact, the OCOL cites the Pan American Health Organization as an example of the success that can be achieved by using the output of machine translation software in combination with revision by professional translators:

Since 1985, the Pan American Health Organization (PAHO) has been using automatic translation software called ENGSPAN to translate most of its documents from English into Spanish. While fully aware that this technology cannot produce perfect results on its own, PAHO management has put in place a process whereby ENGSPAN supports the work of translators rather than eliminates it: the document to be translated is first subject to an automatic correction and/or human revision; it is then translated automatically by the automatic translation software before finally being revised by a professional translator. The results of this approach are conclusive: PAHO has been able to reduce its translation costs per word by $31 \%$; most translations are delivered within specified deadlines; and most readers find the quality acceptable. (OCOL, 2005, p. 59)

However, the Government of Canada's Translation Bureau reacted negatively to this suggestion, stating that it would be unreasonable to use machine translation systems to translate the content of government websites automatically because any reduction in translation costs would inevitably come at the cost of a dramatic drop in quality (OCOL, 2005, pp. 60-61).

The need for quality is not in question. The OCOL maintains that linguistic duality reflects a major commitment that involves not only promoting the equal status of the two official languages throughout Canada, but also the quality of services offered to the public in both English and French (Adam, 2001, p. 17; OCOL, 2005, p. 32). To this end, the OCOL recommends that if an institution is to focus on providing quality service in both official languages, it should adhere to a series of guiding principles, which include, among others:

- Establishing contacts with official language minority communities to determine their need for the services offered; and

- Measuring client satisfaction (Adam, 2001, p. 76). 


\section{Exploring Machine Translation as a Partial Solution for Meeting the Translation Needs of Linguistic Minority Communities}

In summarizing the ideas outlined in the preceding sections, we can identify a number of key points. Firstly, it is clear that members of official language minority communities have substantial unmet translation needs at the level of provincial (and municipal) services, including the lack of French-language material provided on websites. It is also clear that tight budgets coupled with a shortage of professional translators present a substantial roadblock to having this material translated professionally. For this reason, the OCOL has suggested that translation technology should be investigated more fully to determine if it can be used to increase the effectiveness and efficiency of translation services for official language minority communities. At the same time, however, the OCOL warns that a more cost-effective translation solution should not come at the expense of translation quality. Finally, the OCOL recommends that members of the official language minority communities should be consulted to determine their needs and their level of satisfaction with proposed solutions.

With these points in mind, we set out to conduct an investigation into whether machine translation can provide a faster and more cost-effective means of translation which would in turn make it possible for provincial and municipal governments and agencies to offer a wider range of translation services to official language minority communities. As previously mentioned, as an initial case study, we focused on the Fransaskois community.

Machine translation (MT), which refers to the translation of a text by a computer program, is unquestionably faster and cheaper than human translation, but in the vast majority of cases, unedited MT output is of a lesser quality than human translation. A key question that remains to be answered is whether members of the Fransaskois community will accept some form-whether raw or edited-of MT output. In order for the use of MT to be considered viable, the intended recipients of the target texts must be willing to accept the output produced by MT systems. 
As pointed out by the OCOL (Adam, 2001, p. 76), as well as by MT researchers Loffler-Laurian (1996, p. 69) and Trujillo (1999, p. 255), it is the intended recipients of the translated texts who are in the best position to decide whether or not their needs can be suitably met by those texts. Therefore, to find out if members of the Fransaskois community would be accepting of MT, we conducted an experiment and survey in order to determine the extent to which MT can help to meet some of their translation needs.

\subsection{Project Overview}

Experience has clearly shown that MT is not a viable option for all types of texts or situations (Church and Hovy, 1993; LHomme, 1999 , pp. 335-336). It is also generally accepted that MT is better viewed as a translation aid, rather than as an outright replacement for human translators. With this in mind, our investigation has two main goals. The first is to identify which of the translation needs of the Fransaskois community ${ }^{7}$ are not currently being met, and the second is to evaluate the potential of MT for meeting those particular needs.

\subsection{Pre-Testing and Preparatory Work}

As a first step, an initial survey was sent out to members of the Fransaskois community asking them to specify what types of texts, which are currently made available to them only in English, they would also like to have made available in French. Suggestions that were received included tourism-related texts, news items of local interest, and information posted on the websites of the provincial and municipal governments and agencies. Of these suggestions, the latter was the one most frequently given.

We gathered samples of these types of texts and ran preliminary tests using three commercially available desktop

7 In fact, the project will eventually investigate both French- and English-language minority communities in Canada; however, this initial phase is focusing on an investigation of the Fransaskois community, and this paper reports the results of this initial case study. A comparable study investigating the Anglophone community in West Quebec is currently in progress. 
MT systems ${ }^{8}$-Systran, Reverso Pro and Power Translator Professional-to see which of these types of texts were most amenable to MT, and which system would produce the highest quality output.

Based on these initial system tests, we were able to rule out the tourism texts as being viable candidates because the creative style and marketing nature of these texts made them difficult for an MT system to render since such systems tend to produce relatively literal translations. The newspaper stories were also eliminated as reasonable candidates because of the "clipped" or telescoped style of this text type, which makes syntactic disambiguation difficult for MT systems (Hutchins and Somers, 1992, pp. 88-90).

The best candidates were the websites of the provincial and municipal governments and agencies because the texts that they contained were informative and written in a relatively clear, neutral style with reasonably short sentences. This style of text proved to be quite amenable to being processed by an MT system. Most of the words in the texts were already in the system dictionaries, but additional terms could easily be added. Specific subjects that had been requested by Fransaskois community members who responded to the initial survey included disaster planning, ${ }^{9}$ justice, and business. Accordingly, three Englishlanguage texts of approximately 325 words in length were selected as the basis for the survey. All three came from municipal or provincial government websites:

- Keep Safe During Disasters (city of Regina website)

- How to Resolve a Complaint Against the Police (city of Saskatoon website)

8 Commercial systems were selected because they offer a better quality translation than the systems freely available on the Internet. However, it is important to note that all of the systems tested are available for a very reasonable price (less than $\mathrm{CAD} \$ 500$ ) and all permit customization of the dictionaries in order to allow for improved output quality.

9 The initial survey was carried out in September 2005 soon after Hurricane Katrina, which might account for this request. 
- Co-operative Development Assistance Program (province of Saskatchewan website)

Of the three MT systems, Reverso Pro was the one that produced the highest quality results during the preliminary testing phase, so this is the system that was retained for use during the next phase where, for each of these three texts, four translations were produced $^{10}$ :

1. A raw or unrevised machine translation (MT);

2. A rapidly post-edited (RPE) machine translation (i.e., a translation where content errors were corrected, but stylistic changes were not made) $;{ }^{11}$

3. A maximally post-edited (MPE) machine translation (i.e., a translation where both content and style were corrected to produce a text that resembles as closely as possible a human translation);

4. A human translation (HT).

The time and cost for producing each of the four versions was also calculated because whenever a text needs to be translated, the competing parameters of quality, time and cost must always be considered (Lewis, 1995). The methods used for determining the time and cost are described in the following paragraphs, while the actual time and cost required to produce each version are summarized in Table 1.

The raw machine translations were produced by running the texts through the Reverso Pro MT system. Tests revealed that the time required to produce the raw output for each text was approximately two minutes, which included opening the software,

10 See the appendix for an example of one of the texts (Text 2) along with its four translated versions that were used in this experiment.

11 As explained by Allen (2003, p. 302), RPE is "strictly minimal editing on texts in order to remove blatant and significant errors and therefore stylistic issues should not be considered. The objective is to provide the minimum amount of necessary correction work that can be made on a text in order for the text to be fully understandable as a comprehensible element of information." 
importing the source text, and running it through the translation engine. Since each of the texts was relatively short (approximately 325 words), in practical terms, there was no difference in the processing time required to produce each of the raw machine translations. It is worth acknowledging that an initial investment of time would be required in order to install the MT system and to learn how to use it, but this was not factored into the equation since it would be a once-off investment of time, and even the use of conventional translation resources, such as dictionaries or term banks, require an investment of learning time if they are to be used properly.

Two professional translators were hired to help produce the remaining target texts. Clearly it is not possible for two different translators to have precisely the same ability; however, every effort was made to find two translators who had a comparable background and level of skill. Both have an undergraduate degree in translation from a recognized Canadian university, both have approximately two years of professional work experience in a similar setting, and both had followed a master's program at the School of Translation and Interpretation at the University of Ottawa. Translator A produced the human translations, while translator B did the post-editing (both RPE and MPE) of the raw MT output. ${ }^{12}$ Both translators were instructed to keep careful track of the time needed to complete their tasks.

In the case of post-editing, the post-editor began by taking the raw MT output and conducting the RPE. Once the $\mathrm{RPE}$ was complete, the post-editor saved a copy of the RPE text and recorded the amount of time that had been required for this task. Next, with the clock still running, the post-editor revisited the RPE text and gave it a more thorough revision to produce an MPE text, recording the total amount of editing time required. The editing time varied from text to text depending on the number and types of problems the MT system encountered in each text. Then for both the RPE and MPE texts, the time required to produce the raw $\mathrm{MT}$ output (i.e., two minutes) was

12 Translator B's MA thesis dealt with MT and post-editing, so she already had some experience in this area. 
added to the time required for editing to arrive at the total time required to produce the two post-edited target texts.

The cost of producing each version was also calculated. In the case of the raw MT output, the price was set at $\$ 1.68$ on the basis that it took less than two minutes to launch the program, import the text, and generate a raw translation. Obviously, this cost does not include the software purchase price, nor time spent building dictionaries; however, we felt justified in excluding these costs for the following reasons. As noted above, the texts used in this experiment required few entries to be added. In any case, although dictionary-building is not strictly a once-off investment of time, it is an activity that will lessen considerably over time as the dictionaries grow larger and there are fewer entries to be added. Therefore, the amount of time spent on dictionary building in an early stage of an experiment such as this would not be representative of the typical amount of time required to use the system on a long-term basis.

For the other versions, the cost was calculated using the average hourly rates charged by translators $(\$ 53.73)$ and editors $(\$ 50.16)$ as reported in the "Sondage de 2004 sur la tarification et les salaires" published by the Ordre des traducteurs, terminologues et interprètes agréés du Québec (OTTIAQ). Note that although we calculated the post-editing costs using the full rate normally charged by editors, we could potentially have used a lower rate since there is some evidence in the literature to suggest that post-editors are not always paid the full rate. For example, Chesterman and Wagner (2002, p. 125) note that freelance translators contracted by the European Union institutions to post-edit output produced by the Systran MT system are paid "at a rate equivalent to about half the normal rate for freelance translation." Similarly, Vasconcellos and Bostad (1992, p. 67) report that freelance translators hired to post-edit the output of the ENGSPAN MT system used by the PAHO "were being paid 55 percent of the HT rate." If we had used lower rates to calculate the costs of post-editing, then these texts, which already proved to be less expensive to produce than HT, would have been even cheaper as compared to HT. However, for this initial experiment, we decided to be conservative in calculating the costs and so we 
opted to use the full rate charged by editors as reported in the OTTIAQ survey of rates (OTTIAQ, 2004).

The production times and costs for each of the texts, are summarized in Table 1.

\begin{tabular}{|l|l|l|l|}
\hline & Text $\mathbf{1}$ & Text $\mathbf{2}$ & Text 3 \\
\hline Time raw MT & $2 \mathrm{~min}$ & $2 \mathrm{~min}$ & $2 \mathrm{~min}$ \\
\hline Cost raw MT & $\$ 1.68$ & $\$ 1.68$ & $\$ 1.68$ \\
\hline Time RPE & $28 \mathrm{~min}$ & $18 \mathrm{~min}$ & $22 \mathrm{~min}$ \\
\hline Cost RPE & $\$ 23.52$ & $\$ 15.12$ & $\$ 18.48$ \\
\hline Time MPE & $69 \mathrm{~min}$ & $53 \mathrm{~min}$ & $82 \mathrm{~min}$ \\
\hline Cost MPE & $\$ 57.96$ & $\$ 44.52$ & $\$ 68.88$ \\
\hline Time HT & $107 \mathrm{~min}$ & $110 \mathrm{~min}$ & $111 \mathrm{~min}$ \\
\hline Cost HT & $\$ 96.30$ & $\$ 99.00$ & $\$ 99.90$ \\
\hline
\end{tabular}

Table 1. Production time and costs.

The data show that, not surprisingly, raw MT was always the fastest and cheapest method of producing a text, followed by RPE, then MPE, and finally HT. For the texts used in this experiment, it is interesting to note that those produced using MPE-which aims to produce texts that are comparable in quality to HTwere between $30 \%$ and $55 \%$ cheaper than HT and were also produced in a much shorter time frame.

\subsection{Experiment}

Once the translations had been generated, the next step was to consult members of the Fransaskois community to try firstly to identify the reasons why they wanted the texts to be made available in French, and secondly to determine which of the four translated versions presented to them-MT, RPE, MPE or HT-best met their needs. To this end, a survey was developed and made available via the web. Members of the Fransaskois community were contacted and invited to participate in this survey via a mass electronic mailing through groups such as the Assemblée communautaire fransaskoise ( $A C F)$, the Conseil culturel fransaskois, 
the Association canadienne-française de Regina, the Fédération des francophones de Saskatoon, the Association communautaire fransaskoise de Moose Jaw, the Association des parents fransaskois, and the Institut français at the University of Regina.

An interview on Société Radio-Canada en Saskatchewan was also given in which the author provided an overview of the project and invited members of the Fransaskois community to visit the project website and participate in the survey.

As a result of these efforts, a total of 104 respondents participated in the survey.

\subsubsection{Preliminary Survey Questions}

The survey was posted on the web and participants were able to respond anonymously. Because the survey was targeted at members of the Fransaskois community, and specifically at adults, participants were first asked to confirm that they were indeed Francophones living in Saskatchewan and that they were over the age of 18 .

In addition, because of the previously noted resistance of language professionals to the use of MT (e.g. OCOL 2005, pp. 60-61; Bowker and Ehgoetz, 2007), participants were also asked to indicate whether or not they considered themselves to be "language professionals" (e.g., translators, interpreters, terminologists, revisers, writers, language teachers). This issue will be discussed in more detail in an upcoming section.

\subsubsection{Survey of Reasons for Wanting Translation}

Survey participants were next invited to select one of the three English language source texts (see section 3.2), to read it, and to indicate why they would like to have this text made available in French. As stressed by Edwards (1992, p. 48), probing the underlying reason, rather than simply asking yes/no type questions, can provide valuable insight into an official language minority community. A list of possible reasons was provided on the survey, but participants were also able to suggest their own 
reasons. Table 2 summarizes the reasons that were provided by participants with regard to why they would like to have the texts translated into French.

\begin{tabular}{|l|c|}
\hline Reason for wanting translation & \# of responses \\
\hline Cultural preservation & $80(76.9 \%)$ \\
\hline Faster processing of information & $38(36.5 \%)$ \\
\hline Greater confidence in comprehension & $24(23.1 \%)$ \\
\hline Teaching material (e.g. for children, students) & $24(23.1 \%)$ \\
\hline $\begin{array}{l}\text { Improvement of 2 } \\
\text { (verifying information in translation) }\end{array}$ & $12(11.5 \%)$ \\
\hline Don't fully understand original & $6(5.8 \%)$ \\
\hline Other: Equity—it should be my right & $8(7.7 \%)$ \\
\hline
\end{tabular}

\section{Table 2. Reasons for wanting translations ${ }^{13}$}

By far the most common reason for wanting to have the texts translated was as a means of cultural preservation. In other words, a considerable number of the Fransaskois participants in this survey did not tend to view translation as a necessary tool for the functional transfer of linguistic content, but rather as a public acknowledgement of the presence of their language and culture and as a measure of it strength. As observed by Lesage $e t$ al. (2008, p. 15),

The ability of official language minorities to identify with their culture is enhanced when that culture comes out of the shadows of private life and assumes a public face. Only then are citizens able to feel a sense of belonging to something greater than themselves-a collective history, a common endeavour, an ambitious future.

Bernard Lord (2008, p. 21), in reporting the results of his cross-Canada consultations with members of official language minority communities, also underscores the value of culture

13 Note that respondents were allowed to select more than one reason. Based on a population size of 19,500 and a sample size of 104 respondents, the margin of error is $\pm 10 \%$ with a confidence level of $90 \%$. 
for these communities, noting "the importance of culture is undeniable, not only for community vitality but also as a source of economic development and a way of fostering openness toward others." Accordingly, Lord recommends that culture be given special attention in the new strategy for the next phase of the federal government's Action Plan for Official Languages (Lord, 2008, p. 12). ${ }^{14}$ Similarly, François Paré (1997, p. 14) notes that "Whatever its colonial, minority or insular context, the development and prestige of a culture are connected to the survival and the strategic importance of its language in the global linguistic economy." 15 While Parés observation focuses in particular on literary works, the general principle can be extended to the situation encountered in this experiment. In this case, members of the Fransaskois community viewed the translation of material on provincial and municipal government websites as a means of preserving and promoting their culture not so much because of the content of these sites per se, but rather because having a greater amount of material available in French will help to increase the visibility and vitality of their community, which will in turn help to revitalize linguistic duality.

There were other reasons provided which did deal more specifically with translation as a tool for linguistic transfer; however, these reasons were less frequently selected than the view that translation has an important role to play in the linguistic and

14 The original Action Plan for Official Languages (2003) was introduced to give new momentum to the federal policy on official bilingualism. Presented as a 5-year plan (2003-2008), its goal is to enhance and promote linguistic duality and to foster the development and vitality of official language minority communities. It addresses issues relating to health services, immigration, education and literacy; however, it has been criticized for making no specific mention of culture. According to Lesage et al. (2008, p. 8), this omission was deeply disappointing to official language minority communities and left them feeling vulnerable.

15 The original French citation from Pare (1992, p. 18) reads as follows: "Le développement et le prestige d'une culture, indépendamment de son contexte colonial, minoritaire ou insulaire, sont liés à la survie et à l'importance stratégique de cette langue dans l'économie linguistique du monde. » 
cultural preservation of the Fransaskois community. These other reasons included the fact that some people felt that, although they could understand English, they were able to process information more quickly and easily in their native language, and they had greater confidence that they had understood all the details of the text. Some respondents said that they would like to have more French texts available to use as teaching material, either to teach their own children, or to use in a more formal classroom setting. A few others said they were trying to improve their own English language skills, and they would appreciate having a French translation available so that they could verify whether or not they had fully understood the English text. Only a very small number of people claimed not to have been able to understand the English texts sufficiently, while the remaining participants stated that they simply felt that, as Canadians, it should be their right to have this information available in French regardless of how well they could understand the English text.

\subsubsection{Survey of Preferred Type of Translation}

In the following step, participants were asked to read each of the four translated versions of a given text. Then, taking into account the quality of each of the translations, as well as the time and cost required to produce them, they were asked to choose the version that they felt would best meet their needs. The results of their responses are summarized in Table 3.

\begin{tabular}{|l|l|}
\hline Type of translation & \# of respondents selecting this option \\
\hline Human translation & $74(71.1 \%)$ \\
\hline Maximal post-editing (MPE) & $22(21.2 \%)$ \\
\hline Rapid post-editing (MPE) & $8(7.7 \%)$ \\
\hline Raw machine translation & 0 \\
\hline Total & $104(100 \%)$ \\
\hline
\end{tabular}

Table 3. Preferences for type of translation. ${ }^{16}$

16 Based on a population size of 19,500 and a sample size of 104 respondents, the margin of error is $\pm 10 \%$ with a confidence level of $90 \%$. 
On the basis of this survey, it is clear that unrevised MT output is not acceptable to members of the Fransaskois community. Not only was this option not selected by any of the respondents, many of them took the time to voice their dissatisfaction with the quality of the MT in the comments section of the survey. Some of the comments made in this regard included the following:

- "Je ne vois sincèrement pas l'utilité de traduire un texte de façon automatique sans révision. À ce moment, aussi bien le lire en anglais."

- "On peut remarquer que la traduction automatique a une couleur de mot à mot."

- "Les traductions automatiques sans révision sont absolument à éviter si l'on veut que les francophones en milieu minoritaire améliorent leurs connaissances du français écrit.”

At first glance, it would seem that a significant majority of Fransaskois community members (71.1\%) do not seem willing to accept any form of MT, feeling that only HT can fully meet their needs. However, if we take a closer look at the data, some interesting information comes to light.

\subsubsection{Differing Attitudes of Language Professionals and Non-Language Professionals}

As noted above, as part of the survey, respondents had been asked to indicate whether or not they were language professionals. It turns out that of the 104 respondents, 50 (or 48\%) consider themselves to be language professionals, while the remaining 54 (or 52\%) are Francophones who do not work in the language industry. If, as illustrated in Table 4, the data are broken down according to these categories, then a somewhat different picture is revealed.

\begin{tabular}{|l|c|c|}
\hline $\begin{array}{l}\text { Type of } \\
\text { translation }\end{array}$ & $\begin{array}{l}\text { \# of language professionals } \\
\text { selecting this option }\end{array}$ & $\begin{array}{l}\text { \# of non-language professionals } \\
\text { selecting this option }\end{array}$ \\
\hline HT & $44(88 \%)$ & $30(55.6 \%)$ \\
\hline MPE & $6(12 \%)$ & $16(29.6 \%)$ \\
\hline
\end{tabular}




\begin{tabular}{|l|l|l|}
\hline RPE & 0 & $8(14.8 \%)$ \\
\hline Raw MT & 0 & 0 \\
\hline Total & $50(100 \%)$ & $54(100 \%)$ \\
\hline
\end{tabular}

Table 4. Translation preferences of language professionals vs. non-language professionals. ${ }^{17}$

Language professionals, who clearly have extremely high standards and expectations when it comes to language production, insist $88 \%$ of the time that HT is the only acceptable means of producing a target text. In contrast, members of the Fransaskois community who do not work in a language profession are willing to accept some form of post-edited MT close to half the time. The fact that nearly half of the respondents to the survey are language professionals could therefore be skewing the results somewhat since it is unlikely that half the members of the overall Fransaskois community work in the language industry; however, no reliable information about the actual number of Fransaskois working as language professionals could be found.

No doubt it is because language professionals care so passionately about language that they were motivated to respond to the survey; however, this passion also gives them a different perspective on the issue. In addition to having extremely exacting standards in linguistic matters, as reported by Hutchins (2001) and Yuste Rodrigo (2001), many language professionals seem to feel threatened by MT, fearing that it may lead to a loss of livelihood for them. Church and Hovy (1993, p. 249) make a related observation when they note that many translators do not wish to become post-editors-a task that they perceive as being tedious and dreary. Moreover, they may also fear that the use of MT will result in the production of lower quality texts, which may in turn hurt the reputation of their profession in general. The findings of the survey therefore support the point made by Hutchins (2001) that the general population may be more willing

17 Note that it was not possible to calculate a margin of error or confidence level for this data because no reliable information could be found about the population of language professionals in the Fransaskois community. 
than translators to accept MT. In the words of Hutchins (2001), "While poor quality output is not acceptable to translators, it is acceptable to most of the rest of the population, if they want immediate information, and the on-line 'culture' demands rapid access to and processing of information."

Interestingly, experiments using $\mathrm{MT}$ in intelligence agencies and in the military produced similar observations. For instance, Holland et al. (2000, p. 246) note that agents who work as language professionals in intelligence agencies have a relatively high degree of translation training and considerable translation experience. In general these agents are much less tolerant of machine translation than are soldier-linguists in the military, who have considerably less formal training and experience in translation. In fact, when compared to intelligence agents, it has been observed that "soldiers seem disproportionately welcoming of automatic translation" (Hernandez et al., 2004, p. 95) and that "they [soldiers] are tolerant of lower quality translations" (Holland et al., 2000, p. 246).

Returning to our own experiment, it is interesting to note the following comments that were made by some of the survey respondents who were language professionals. These comments display a significant intolerance towards MT and a clear preference for HT.

- "À mon avis la seule solution est de traduire tout texte par un traducteur humain, ou ne pas traduire du tout."

- "Aller vers un système de traduction automatique met notre langue à risque dans des contextes de vie où les 2 langues officielles se côtoient et crée pour celle-ci des interférences et nous en perdons parfois les mots justes."

- " Moi je préfère la traduction faite par un traducteur."

- “Les 'systèmes de traduction automatique' sont des monstres qui défigurent la langue française.”

\subsection{Discussion}

It has been observed by numerous MT researchers (e.g. Church and Hovy, 1993; Lewis, 1997; Miller et al., 2001), that the 
acceptability of MT output is not absolute; rather, it varies according to the purpose for which the text will be used. In our experiment, some correlations can be observed between the reasons why the translation is desired and the level of acceptance of MT. As pointed out by O'Hagan and Ashworth (2002, p. 9) and Wagner et al. (2002, p. 90), MT seems to be most useful in cases where people simply want to have a general understanding of a text (i.e., assimilation of information), whereas it is typically less helpful when people want to publish a text for others to read (i.e., dissemination of information). Our data supports these observations. For instance, it reveals that there was a greater willingness to accept post-edited MT in cases where the respondents wanted the translations in order to be able to process information more quickly and with greater confidence, or to improve their own knowledge of English-all of which can be considered forms of information assimilation. The respondents who wanted $\mathrm{MT}$ for reasons of personal assimilation of information were people who did not work in the language industries. This is not surprising given that language professionals are extremely fluent in their second language and are thus able to process and understand the English texts quickly and easily without the need for assistance with the task of information assimilation.

In contrast, respondents who view translation as a means of preserving or promoting a culture, of providing equity for the French language, and of furnishing material that could be used to teach French-all of which are forms of information dissemination-were those who preferred HT. The respondents who made these choices were mostly members of the language profession.

Therefore, the data generated by this experiment support observations made by researchers such as Vasconcellos and Bostad (1992, p. 69), Lewis (1997, p. 18) and Chesterman and Wagner (2002, p. 87) that in cases motivated by information assimilation, people will often be more willing to accept a somewhat lower quality translation in return for a lower price and faster turnaround time. In the case of official language minority communities in Canada, it seems that an acceptance of 
MT could have the potential to lead to the provision of a wider range of translation services since MT-even if it is post-edited using $\mathrm{RPE}$ or $\mathrm{MPE}$ - is less expensive and takes less time to produce than HT. Conversely, in cases motivated by information dissemination, and particularly by the desire to increase the vitality and raise the visibility of a community and to generate an acknowledgement of its language and culture, quality remains of paramount importance, and in such cases any form of MTeven post-edited MT-is less acceptable regardless of the fact that it is faster and less expensive to produce.

Another very interesting observation arising from this experiment is that the very mention of machine translation evokes a strong reaction from many people, and particularly from members of the language profession. In this experiment, the four versions of the texts were clearly labelled as being one of MT, RPE, MPE or HT. In hindsight, we feel that this was a mistake since some of the respondents clearly made the decision "on principle" that they would not accept texts that been produced with the assistance of MT software. For example, in the section of the survey where participants were invited to make comments, one respondent, who happened to be a language professional, stated:

- "J'ai choisi le texte traduit par un traducteur au lieu de la traduction automatique postéditée par un traducteur de façon maximale, mais j'admets que ce dernier était tout de même très acceptable..."

To prevent this type of bias and ensure a more objective response in future experiments, it would be advisable not to specifically label the different versions of the translations. Details regarding production time and cost for each text should still be provided, but the labels of MT, MPE, RPE and HT should be removed to prevent respondents who harbour prejudices against MT from rejecting these translations on principle.

The strong reactions of language professionals to MT in our experiment also raise other questions, such as why they feel so negatively towards MT, and whether or not their disdain for MT is well-founded. As noted above, fear of loss of livelihood 
or fear that they will be forced to become post-editors could potentially explain these negative feelings. In addition, given that the majority of language professionals viewed translation as a means of cultural preservation and promotion, it could be that they also feel that people, not machines, should be the ones to uphold culture in their community. However, an additional hypothesis that we have developed is that the way in which translation technology is taught in translator training programs may contribute to the negative attitude that translators hold towards MT, as well as towards other types of translation tools. With this in mind, we are in the process of conducting another research project to investigate more fully the place of technology in the translator training curriculum.

\section{Looking Ahead: Technology and Translator Training}

The majority of people working in translation or related professions (e.g. terminology, revision) hold a degree in translation. ${ }^{18}$ For the past several decades, technology has become an increasingly important component of these professions, and it would be unthinkable for any training program for translators not to include some kind of introduction to the use of translation technologies. Indeed, one would be hard pressed to identify a translator training program today that does not offer some form of instruction in the use of technologies. However, it is not entirely clear to what extent the training that is offered is truly effective.

For instance, there is evidence that employers would be happier if translators arrived in the workforce with a better knowledge of specialized translation tools (e.g. CTISC, 1999, p. 83; Bowker, 2004, p. 970). Meanwhile, numerous studies also reveal that a relatively low percentage of translators actively use translation technology in their daily work (Wheatley, 2003; Fulford and Granell-Zafra, 2005).

18 At least, this is the case in Canada, where I live and work. According to the Canadian Translation Industry Sectoral Committee, more than $80 \%$ of Canadian translation professionals hold a university degree (CTISC, 1999, p. 17). 
This raises a question as to the cause of the apparent disconnect between market expectations and translator attitudes. Could the problem be partially rooted in the way in which translation technology is taught? According to Wheatley (2003) and Granell-Zafra (2005), the answer is yes. Their research reveals that one key reason that many translators have not embraced translation technologies is because they lack knowledge about or training with such tools. Therefore, there would seem to be a clear need to provide translators with more knowledge about translation technology.

The best means of providing this knowledge, however, may not be as clearly obvious. Tasks such as developing and updating resources for teaching translation tools, making them readily available to both students and trainers, and integrating them into translation programs involve a number of challenges at both a practical and theoretical level, including:

- wide variation in students' and instructors' attitudes towards technology;

- wide variation in students' and instructors' levels of comfort and experience with technology;

- differing learning needs and preferences, which creates a need for different training strategies;

- decentralization of resources and lack of knowledge transfer procedures;

- relegation of technology training to "core" technology courses and lack of integration of technology into other courses (e.g. specialized translation, comparative stylistics, writing), where the benefits of using such tools truly become clear.

\section{The Collection of Electronic Resources in Translation Technologies} (CERTT) project, which is being developed at the University of Ottawa, aims to deal with some of these problematic issues by building an integrated bank of resources for learning and using translation tools that will be available to faculty and students for both classroom and personal use. By building a centralized online collection of tutorials, exercises, questions for reflection, corpora, frequently asked questions, readings, links to external resources, and other information, the CERTT project offers students and trainers an opportunity-along with the assistance they need- 
to integrate tools more fully into their daily learning, teaching, research and other academic activities.

However, building the CERTT resource is only one aspect of this research project. We feel it is critically important to investigate how the attitudes and motivations of translators and trainers are shaping the use (or lack of use) of technology, and to see if new educational techniques can effectively re-orient these attitudes and motivations to arrive at training program that can better meet the needs of $21^{\text {st }}$ century students without compromising those elements of the training program that traditional trainers have always valued.

To this end, a pilot study is being carried out at the University of Ottawa in the 2007/2008 academic year. As part of this study, surveys will be conducted at the beginning of the semester to determine the trainers' and students' comfort levels with technology, as well as their attitudes towards technology and even the sources of these attitudes (e.g. discomfort with technology, fear of change, industry myths or apocryphal tales, anecdotal experiences, etc.). During the semester, the CERTT resource will be introduced and assistance will be given to trainers who would like to integrate some form of translation technology into their courses, whether these are practical translation courses, courses on terminology, courses on language or writing skills, etc. At the end of the semester, follow-up surveys will be conducted to track how attitudes towards and comfort levels with translation tools may have changed or evolved, and feedback will be gathered about the strengths and weaknesses of the CERTT resource and the integrated approach with a view to improving these in the future.

At the end of this study, we hope to have a much better understanding of the attitudes that translators have towards technology. Returning to the specific case of MT, which is the main focus of this paper, we hope that such an understanding will then permit us to help a greater number of translators to begin to see some of the possible benefits that could be offered by MT, as well as to be able to identify clearly situations where the use of MT would be appropriate and useful, and to rule out instances where MT should not be employed. 
As pointed out by researchers such as Melby (1997) and Hutchins (2001), ideally, human translation and machine translation should complement each other, rather than compete with one another. The real challenge, as observed by Kay (1997, p. 3), is to identify "the proper place of men and machines in language translation". Hopefully, a more integrated approach to translator training, such as the CERTT approach which encourages critical reflection on the potential applications, possibilities and limits of translation technology, will better prepare translators to meet this challenge. By addressing concerns about uncritical use of tools and providing essential information to define the uses to which tools may be put, CERTT aims to encourage users to develop realistic expectations with regard to technologies and their applications, and to recognize the strengths and weaknesses of various tools. Finally, CERTT will encourage critical reflection-based on concrete data and experience-that can help translators to develop more considered and reasoned attitudes toward technologies. This in turn could facilitate a rapprochement between technology cynics and supporters, which may eventually bring us full circle to a position where a wider range of translation services can be offered to Canadians living in official language minority communities.

\section{Acknowledgements}

The research reported in this paper has been carried out with the assistance of funding from the Official Languages Research and Dissemination Program (a strategic joint initiative of the Social Sciences and Humanities Research Council and the Department of Canadian Heritage), the Social Sciences and Humanities Research Council Standard Research Grants program, the Centre canadien de recherche sur les francophonies en milieu minoritaire (CRFM) based at the University of Regina, and the University of Ottawa's Centre for University Teaching. I would also like to thank Nicolle Sauvage and Elizabeth Marshman for their valuable assistance with aspects of this project. I am also grateful to the anonymous reviewers for their constructive comments which helped to improve this paper.

University OF OtTaWA 


\section{APPENDIX}

This appendix contains one of the three source texts (Text 2) used in this research project along with the four translated versions of this text-raw (unrevised) machine translation output, rapidly post-edited machine translation output, maximally post-edited machine translation output, and human translation. Data is also provided with regard to the time and cost required to produce each of the translated versions.

\begin{tabular}{|l|l|}
\hline Text & Original English-language source text \\
\hline Word count & 331 words \\
\hline Source & $\begin{array}{l}\text { http://www.police.saskatoon.sk.ca/complaints.htm } \\
\text { (accessed January 6, 2006) }\end{array}$ \\
\hline
\end{tabular}

\section{HOW TO RESOLVE A COMPLAINT AGAINST THE POLICE}

The Complaints Investigator is appointed by the government in order to ensure a fair and thorough investigation of a complaint against the police.

One of the main functions of the police is the protection of the general public. Police Departments realize that their officers must maintain a high degree of public support to effectively carry out their duties. It is recognized that occasions arise when a citizen feels he or she has not been treated fairly by a police officer and for that reason a Citizen Complaint Procedure was set out in The Police Act, 1990. It is in the best interest of the public and the police to have citizens' complaints resolved in order to maintain the spirit of co-operation that now exists.

\section{WHAT IS A COMPLAINT}

A complaint is an allegation by any member of the public concerning the conduct of any member of a Municipal Police Service in relation to the performance of his/her duty or function. 


\section{WHEN YOU SHOULD COMPLAIN}

To ensure that the best possible service is provided to you, it is in everyone's best interest that you make your complaint as soon as possible. Pursuant to The Police Act, 1990, no public complaint will be received after the expiry of six months from the date of the incident.

\section{HOWTO REGISTER A COMPLAINT}

You may report a complaint in person or by writing to:

- Police Service

- Office of the Complaints Investigator

or; by completion of the prescribed form and a written statement.

An acknowledgement of your complaint will be forwarded to you from the Complaints Investigator.

Where the investigation is not completed within fortyfive days, you will receive an interim report on the status of your complaint with a further report every thirty days until the matter is concluded.

At the conclusion of the investigation into your complaint you will be advised by the Complaints Investigator of the results of the investigation and the review.

\begin{tabular}{|l|l|}
\hline Type of translation & Raw (unrevised) machine translation output \\
\hline Time & 2 minutes \\
\hline Production cost & $\$ 1.68$ \\
\hline
\end{tabular}

COMMENT RÉSOUDRE UNE PLAINTE CONTRE LA POLICE

L'Investigateur de Plaintes est nommé par le gouvernement pour assurer une enquête juste et minutieuse d'une plainte contre la police. 
Une des fonctions principales de la police est la protection du grand public. Des départements de Police se rendent compte que leurs officiers doivent maintenir un haut degré d'appui public pour efficacement effectuer leurs devoirs. Il est reconnu que les occasions surgissent quand un citoyen sent il ou elle n'a pas été traitée impartialement par un policier et c'est pourquoi une Procédure de Plainte de Citoyen a été exposée dans l'Acte de Police, 1990. Il est dans le meilleur intérêt du public et la police pour faire résoudre les plaintes des citoyens pour maintenir l'esprit de coopération qui existe maintenant.

\section{CE QUI EST UNE PLAINTE}

Une plainte est une allégation par n'importe quel membre du public concernant la conduite de n'importe quel membre d'un Service Municipal de Police par rapport à l'exécution de son/son devoir ou fonction.

\section{QUAND VOUS DEVRIEZ VOUS PLAINDRE}

Pour assurer que l'on vous fournit le meilleur service possible, c'est dans le meilleur intérêt de chacun que vous faites votre plainte aussitôt que possible. Conformément à l'Acte de Police, 1990, aucune plainte publique ne sera reçue après l'expiration de six mois de la date de l'incident.

\section{COMMENT ENREGISTRER UNE PLAINTE}

Vous pouvez annoncer une plainte dans la personne ou en écrivant :

- Service de Police

- Bureau de l'Investigateur de Plaintes

$\mathrm{Ou}$; par achèvement de la forme prescrite et une déclaration écrite.

Une reconnaissance de votre plainte vous sera expédiée de l'Investigateur de Plaintes.

Où l'enquête n'est pas achevée dans quarante-cinq jours, vous recevrez un intérimaire font un rapport sur le statut de votre 
plainte avec un nouveau rapport tous les trente jours jusqu'à ce que l'on conclue la question.

À la fin de l'enquête dans votre plainte vous prendrez acte par l'Investigateur de Plaintes des résultats de l'enquête et la revue.

\begin{tabular}{|l|l|}
\hline Type of translation & $\begin{array}{l}\text { Rapidly post-edited machine translation output } \\
\text { (i.e., correcting errors of content but not of style) }\end{array}$ \\
\hline Time & 18 minutes \\
\hline Production cost & $\$ 15.12$ \\
\hline
\end{tabular}

\section{COMMENT RÉSOUDRE UNE PLAINTE CONTRE LA POLICE}

L'enquêteur de Plaintes est nommé par le gouvernement pour assurer une enquête juste et minutieuse d'une plainte contre la police.

Une des fonctions principales de la police est la protection du grand public. Des départements de Police se rendent compte que leurs agents doivent maintenir un haut degré d'appui public pour efficacement effectuer leurs devoirs. Il est reconnu que les occasions surgissent quand un citoyen sent qu'il ou elle n'a pas été traité(e) impartialement par un policier et c'est pourquoi une Procédure de Plainte de Citoyen est prévue dans la Loi de 1990 sur la police. Il est dans le meilleur intérêt du public et de la police de résoudre les plaintes des citoyens pour maintenir l'esprit de coopération qui existe maintenant.

\section{CE QUI EST UNE PLAINTE}

Une plainte est une allégation par n'importe quel membre du public concernant la conduite de n'importe quel membre d'un Service Municipal de Police par rapport à l'exécution de son devoir ou de sa fonction.

\section{QUAND VOUS DEVRIEZ VOUS PLAINDRE}

Pour assurer que l'on vous fournit le meilleur service possible, c'est dans le meilleur intérêt de chacun que votre plainte soit déposée 
aussitôt que possible. Conformément à la Loi de 1990 sur la police, aucune plainte publique ne sera reçue après l'expiration de six mois de la date de l'incident.

\section{COMMENT ENREGISTRER UNE PLAINTE}

Vous pouvez annoncer une plainte en personne ou en écrivant :

- au Service de Police

- au Bureau de l'enquêteur de Plaintes

Ou en remplissant le formulaire prescrit et une déclaration écrite.

Une attestation de votre plainte vous sera expédiée par l'enquêteur de Plaintes.

Si l'enquête n'est pas achevée dans quarante-cinq jours, vous recevrez un rapport provisoire sur le statut de votre plainte avec un nouveau rapport tous les trente jours jusqu'à ce que l'on conclue la question.

À la fin de l'enquête sur votre plainte, vous serez informé par l'enquêteur de Plaintes des résultats de l'enquête et de l'examen.

\begin{tabular}{|l|l|}
\hline Type of translation & $\begin{array}{l}\text { Maximally post-edited machine translation output } \\
\text { (i.e., correcting both errors of content and style) }\end{array}$ \\
\hline Time & 53 minutes \\
\hline Production cost & $\$ 44.52$ \\
\hline
\end{tabular}

\section{COMMENT RÉGLER UNE PLAINTE CONTRE LA POLICE}

L'enquêteur sur les plaintes est nommé par le gouvernement pour assurer la tenue d'enquêtes justes et minutieuses sur les plaintes contre la police.

Une des principales fonctions de la police est la protection du grand public. Les services de police se rendent compte que leurs agents doivent maintenir un haut niveau d'appui public pour accomplir leur devoir efficacement. Il peut arriver qu'un 
citoyen sente qu'il a été traité de façon injuste par un policier. C'est pourquoi la Loi de 1990 sur la police prévoit une Procédure de traitement des plaintes des citoyens. Il est dans le meilleur intérêt du public et de la police de régler les plaintes des citoyens pour maintenir l'esprit de collaboration qui existe actuellement.

\section{QU'EST-CE QU'UNE PLAINTE}

Une plainte est une allégation par n'importe quel membre du public concernant la conduite de n'importe quel membre d'un service de police municipal par rapport à l'exercice de son devoir ou de ses fonctions.

\section{QUAND VOUS DEVRIEZ VOUS PLAINDRE}

Pour obtenir le meilleur service possible, il est dans le meilleur intérêt de chacun que vous déposiez votre plainte aussitôt que possible. Conformément à la Loi de 1990 sur la police, aucune plainte du public ne sera acceptée après la période de six mois suivant la date de l'incident.

\section{COMMENT DÉPOSER UNE PLAINTE}

Vous pouvez déposer une plainte en personne ou en écrivant :

- au service de police

- au bureau de l'enquêteur sur les plaintes

ou en soumettant le formulaire prévu dûment rempli et en une déclaration écrite.

Une attestation de votre plainte vous sera expédiée par l'enquêteur sur les plaintes.

Si l'enquête n'est pas terminée dans les quarante-cinq jours, vous recevrez un rapport provisoire sur le statut de votre plainte, suivi d'un nouveau rapport tous les trente jours jusqu'à ce que la question soit réglée.

À la fin de l'enquête sur votre plainte, vous serez informé par l'enquêteur sur les plaintes des résultats de l'enquête et de l'examen. 


\begin{tabular}{|l|l|}
\hline Type of translation & Human translation \\
\hline Time & 1 h 50 min $(110$ minutes $)$ \\
\hline Production cost & $\$ 99.30$ \\
\hline
\end{tabular}

\section{COMMENT RÉSOUDRE UNE PLAINTE CONTRE LA POLICE}

Le responsable des plaintes est mandaté par le gouvernement pour assurer un traitement juste et équitable lorsqu'une enquête est menée relativement à une plainte déposée contre la police.

L'une des responsabilités majeures de la police est la protection civile. Les services de police sont conscients que leurs officiers doivent maintenir un niveau élevé de confiance entre eux et les citoyens afin d'intervenir de façon efficace lors de l'exercice de leurs fonctions. Malgré tout, il arrive souvent qu'un citoyen puisse sentir qu'il (elle) n'a pas été traité(e) convenablement par un policier. Pour cette raison, une procédure de traitement des plaintes a été mise en place (The Police Act, 1990). Cette loi vise l'intérêt supérieur du public et de la police et a pour objectif de maintenir l'esprit de coopération qui existe actuellement entre les citoyens et les policiers en offrant l'aide requise pour résoudre les cas de plaintes.

\section{QU'EST-CE QU'UNE PLAINTE?}

Une plainte est une allégation avancée par un membre du public concernant la conduite d'un membre d'un corps policier lors de l'exécution de ses fonctions.

\section{QUAND DEVEZ-VOUS DÉPOSER UNE PLAINTE}

Afin de recevoir un meilleur service, c'est dans l'intérêt de tous que vos déposiez votre plainte le plus tôt possible. En vertu de la Loi (The Police Act, 1990), aucune plainte provenant du public ne sera traitée passée une période de six mois suivant l'incident. 


\section{COMMENT DÉPOSER UNE PLAINTE}

Vous pouvez déposer une plainte en personne ou le faire par écrit au :

- $\quad$ service de police

- bureau du responsable des plaintes, ou

en remplissant le formulaire approprié et en rédigeant une déclaration écrite.

Le responsable des plaintes vous fera parvenir un accusé de réception.

Si l'enquête n'est pas terminée dans un délai de 45 jours suivant la réception de votre plainte, vous recevrez alors un rapport intérimaire vous informant du statut de l'enquête et par la suite un rapport tous les mois, et ceci, jusqu'à la fin de l'enquête.

Lorsque l'enquête sera terminée, vous en serez informé par le responsable des plaintes qui vous communiquera les résultats et vous fournira un compte rendu de la situation. 


\section{References}

ACTION PLAN FOR OFFICIAL LANGUAGES (2003). The Next Act: New Momentum For Canada's Linguistic Duality. Ottawa: Minister of Supply and Services Canada [http://www. pco-bcp.gc.ca/olo/default.asp?Language $=\mathrm{E} \& \mathrm{Page}=\mathrm{Action} \& \mathrm{doc}$ =cover_e.htm] Accessed April 15, 2008.

ADAM, Dyane (2000a). A Call for Action: Cross-Canada Consultations by the Commissioner of Official Languages. Ottawa, Office of the Commissioner of Official Languages.

ADAM, Dyane (2000b). Annual Report of the Office of the Commissioner of Official Languages (1999-2000). Ottawa, Minister of Public Works and Government Services Canada. [http://www. ocol-clo.gc.ca/html/ar_ra_1999_00_e.php] Accessed July 26, 2007.

ADAM, Dyane (2001). Annual Report of the Office of the Commissioner of Official Languages (2000-2001). Ottawa, Minister of Public Works and Government Services Canada. [http://www. ocol-clo.gc.ca/html/ar_ra_2000_01_e.php] Accessed July 26, 2007.

ADAM, Dyane (2004). Annual Report of the Office of the Commissioner of Official Languages (2003-2004). Ottawa, Minister of Public Works and Government Services Canada. [http://www. ocol-clo.gc.ca/html/ar_ra_2003_04_e.php] Accessed July 26, 2007.

ADAM, Dyane (2005). Annual Report of the Office of the Commissioner of Official Languages (2004-200), Vols. 1 and 2. Ottawa, Minister of Public Works and Government Services Canada. [http://www.ocol-clo.gc.ca/docs/e/2004_05_e.pdf] Accessed July 26, 2007.

ADAM, Dyane (2006). Annual Report of the Office of the Commissioner of Official Languages (2005-2006). Ottawa, Minister of Public Works and Government Services Canada. [http://www. ocol-clo.gc.ca/docs/e/2005_06_e.pdf] Accessed July 26, 2007. 
ALLEN, Jeff (2003). "Post-Editing." In H. Somers, ed., Computers and Translation: A Translator's Guide. Amsterdam/Philadelphia, John Benjamins, pp. 297-317.

BONIN, Kenneth-Roy and Michael KELLY (2008). The Role of Canadian Federal Research Funding Agencies in the Promotion of Official Languages. Report prepared for the Office of the Commissioner of Official Languages. Ottawa, Minister of Public Works and Government Services Canada. [http://www.ocol-clo. gc.ca/docs/e/promotion_e.pdf] Accessed April 10, 2008.

BOURGEOIS, Daniel, Wilfred DENIS, Donald DENNIE and Marc L. JOHNSON (2007). Provincial and Territorial Government Contributions to the Development of Francophone Minority Communities: Assessment and Projections. Moncton, Canada: Canadian Institute for Research on Linguistic Minorities. [http://www.icrml.ca/images/stories/documents/en/ cmfc-eng.pdf] Accessed April 1, 2008.

BOWKER, Lynne and Melissa EHGOETZ (2007). "Exploring User Acceptance of Machine Translation Output: A Recipient Evaluation." In D. Kenny and K. Ryou, eds., Across Boundaries: International Perspectives on Translation Studies. Newcastle-uponTyne, Cambridge Scholars Publishing.

CANADIAN TRANSLATION INDUSTRY SECTORAL COMMITTEE (CTISC) (1999). Survey of the Canadian Translation Industry: Human Resources and Export Development Strategy. [www.uottawa.ca/associations/csict/princi-e.htm] Accessed August 15, 2007.

CERTT Project. [http://aix1.uottawa.ca/ certt] Accessed April 15, 2008.

CHESTERMAN, Andrew and Emma WAGNER (2002). Can Theory Help Translators? A Dialogue Between the Ivory Tower and the Wordface. Manchester, St. Jerome Publishing.

CHURCH, Kenneth W. and Eduard H. HOVY (1993). "Good Applications for Crummy Machine Translation." Machine Translation 8, pp. 239-258. 
CHURCHILL, Stacy (1998). Official Languages in Canada: Changing the Language Landscape. Ottawa, Department of Canadian Heritage.

CLAVET, Alain (2002). French on the Internet: Key to the Canadian Identity and the Knowledge Economy. Follow-Up Study by the Commissioner of Official Languages. Ottawa, Minister of Public Works and Government Services Canada. [http://www. ocol-clo.gc.ca/docs/e/fr_Internet_id_can-2002_e.pdf] Accessed July 26, 2007.

EDWARDS, J. (1992). "Sociopolitical Aspects of Language Maintenance and Loss: Towards a Typology of Minority Language Situations." In W. Fase, K. Jaspaert and S. Kroon, eds., Maintenance and Loss of Minority Languages. Amsterdam/ Philadelphia, John Benjamins, pp. 37-54.

FULFORD, Heather and Joaquin GRANELL-ZAFRA (2005). "Translation and Technology: A Study of UK Freelance Translators." The Journal of Specialized Translation (JoSTrans) 4. [http://www.jostrans.org/issue04/art_fulford_zafra.php] Accessed August 7, 2007.

GASPARI, Federico and John HUTCHINS (2007). "Online and Free! Ten Years of Online Machine Translation: Origins, Developments, Current Use and Future Prospects." In B. Maegaard, ed., Proceedings of Machine Translation Summit XI. Copenhagen, EAMT/IAMT, pp. 199-206. [http://www.mtarchive.info/MTS-2007-Gaspari-1.pdf] Accessed March 31, 2008.

HERNANDEZ, L., J. TURNER and M. HOLLAND (2004). "Feedback from the Field: The Challenge of Users in Motion." In R. E. Frederking and K. B. Taylor, eds., Machine Translation: From Real Users to Research. Berlin, Springer, pp. 94-101.

HOLLAND, M., C. SCHLESIGER and C. TATE (2000). "Evaluating Embedded Machine Translation in Military Field Exercises." In J. S. White, ed., Envisioning Machine Translation in the Information Future. Berlin, Springer, pp. 239-247. 
HUTCHINS, John (2001). "Machine Translation and Human Translation: In Competition or in Complementation?" International Journal of Translation, 13(1-2), pp. 5-20.

HUTCHINS, W. John and Harold L. SOMERS (1992). An Introduction to Machine Translation. London, Academic Press.

KAY, Martin (1997[1980]) “The Proper Place of Men and Machines in Language Translation," Machine Translation 12 (12), pp. 3-23.

LESAGE, Micheline and Associates and Meta4 Creative Communications (2008). Federal Government Support for the Arts and Culture in Official Language Minority Communities. Report prepared for the Office of the Commissioner of Official Languages. Ottawa, Minister of Public Works and Government Services [http://www.ocol-clo.gc.ca/docs/e/arts_culture_e.pdf] Accessed April 10, 2008.

LEWIS, Terence (1995). "Can We Make Do with Near Human Quality?" Proceedings of Translating and the Computer 17. London, Aslib.

LEWIS, Terence (1997). "Do You Have a Translation Tool Strategy?” Language International 9 (5), pp. 16-18.

L'HOMME, Marie-Claude (1999). Initiation à la traductique. Brossard, Linguatech.

LOFFLER-LAURIAN, Anne-Marie (1996). La traduction automatique. Villeneuve d'Ascq, Presses Universitaires du Septentrion.

LORD, Bernard (2008). Report on the Government of Canada's Consultations on Linguistic Duality and Official Languages. Report submitted to the Minister of Canadian Heritage, Status of Women and Official Languages. February 28, 2008. [http://www. canadianheritage.gc.ca/pc-ch/consultations/lo-ol_2008/lord_e. pdf] Accessed April 3, 2008. 
MELBY, Alan (1997). "Some Notes on The Proper Place of Men and Machines in Language Translation," Machine Translation 12, pp. 29-34.

MILLER, Keith J., Donna M. GATES, Nancy UNDERWOOD and Josemina MAGDALEN (2001). "Evaluation of Machine Translation Output for an Unknown Source Language: Report of an ISLE-based investigation," Proceedings of the Machine Translation Summit VIII. Santiago de Compostela, Spain (September 2001). [http://www.eamt.org/summitVIII/papers/ miller-2.pdf] Accessed August 13, 2007.

OFFICE OF THE COMMISSIONER OF OFFICIAL LANGUAGES (OCOL) (1999). The Government of Canada and French on the Internet. Ottawa, Minister of Public Works and Government Services Canada [http://www.ocol-clo.gc.ca/html/ gov_fr_internet_gouv_fran_e.php] Accessed July 26, 2007.

OFFICE OF THE COMMISSIONER OF OFFICIAL LANGUAGES (OCOL) (2001a). National Report on Service to the Public in English and French: Time for a Change in Culture. Ottawa, Minister of Public Works and Government Services Canada. [http://www.ocol-clo.gc.ca/html/stu_etu_ service_042001_e.php] Accessed August 8, 2007.

OFFICE OF THE COMMISSIONER OF OFFICIAL LANGUAGES (OCOL) (2001b). Our Official Languages: As a Century Ends and a Millennium Begins. Ottawa, Minister of Public Works and Government Services Canada.

OFFICE OF THE COMMISSIONER OF OFFICIAL LANGUAGES (OCOL) (2005). Bridging the Digital Divide: Official Languages on the Internet. Ottawa, Minister of Public Works and Government Services Canada. [http://www.ocol-clo. gc.ca/html/stu_etu_092005_e.php] Accessed July 26, 2007.

OFFICE OF THE COMMISSIONER OF OFFICIAL LANGUAGES (OCOL) (2007). French Culture and Learning French as a Second Language: Perceptions of the Saskatcherwan Public. Ottawa, Minister of Public Works and Government Services 
Canada. [http://www.ocol-clo.gc.ca/docs/e/perceptions_e.pdf] Accessed August 8, 2007.

O'HAGAN, Minako and David ASHWORTH (2002). Translation-Mediated Communication in a Digital World. Clevedon, Multilingual Matters.

ORDRE DES TRADUCTEURS, TERMINOLOGUES ET INTERPRÈTES AGRÉÉS DU QUÉBEC (OTTIAQ) (2004). "Sondage de 2004 sur la tarification et les salaires ». [Document distributed to OTTIAQmembers.]

PARÉ, François (1992). Les littératures de l'exiguïté. Hearst, Les Éditions du Nordir.

PARÉ, François (1997). Exiguity: Reflections on the Margins of Literature. Trans. Lin Burman. Waterloo, Wilfred Laurier University Press.

STANDING JOINT COMMITTEE ON OFFICIAL LANGUAGES (SJCOL) (2002). The Official Language Minority Communities Told Us... Ottawa, Minister of Public Works and Government Services Canada. [http://cmte.parl.gc.ca/cmte/ CommitteePublication. aspx? COM=223\&Lang=1\&Source $\mathrm{Id}=37139]$ Accessed August 8, 2007.

STATISTICS CANADA. 2006 Census. [http://www12.statcan. ca/english/Search/secondary_search_index.cfm] Accessed April 10, 2008.

TRUJILLO, Arturo (1999). Translation Engines: Techniques for Machine Translation. London/New York, Springer Verlag.

VASCONCELLOS, Muriel and Dale A. BOSTAD (1992). "Machine Translation in a High-Volume Translation Environment." In J. Newton, ed., Computers in Translation: A Practical Appraisal. London/New York, Routledge, pp. 58-77.

WAGNER, Emma, Svend BECH and Jesús M. MARTÍNEZ (2002). Translating for the European Union Institutions. Manchester, St. Jerome Publishing. 
WHEATLEY, Alan (2003). "eCoLoRe (eContent Localization Resources for Translator Training) A Major Breakthrough for Translator Training." Globalization Insider, Vol. XII, Issue 2,4 [http://www.translationdirectory.com/article450.htm] Accessed August 8, 2007.

YUSTE RODRIGO, Elia (2001). "Making MT Commonplace in Translation Training Curricula: Too Many Misconceptions, So Much Potential!" Proceedings of the Machine Translation Summit _VIII Teaching MT Workshop. Santiago de Compostela, Spain (September 2001). [http://www.dlsi.ua.es/tmt/docum/TMT7. pdf] Accessed August 13, 2007.

ABSTRACT: Official Language Minority Communities,
Machine Translation, and Translator Education: Reflections
on the Status Quo and Considerations for the Future Owing largely to budgetary pressures, official language minority communities in Canada have a great number of unmet translation needs. The use of machine translation presents the possibility of a cost-effective solution, but only if members of this community are willing to accept this form of translation. This paper reports on an experiment whereby members of one official language minority community in Canada-the Fransaskois-were surveyed to determine their level of acceptance of machine translation. Results show that while many Fransaskois are quite favourable to the possibility of using post-edited machine translation, those who are also language professionals are extremely opposed to the use of any form of machine translation. This finding prompts a reflection on whether the way in which translators are trained in the use of technology could be an underlying factor in their reaction to machine translation use, which in turn leads to a proposal for a new approach to integrating technology more fully into translator training programs.

RÉSUMÉ : Les communautés minoritaires de langue officielle, la traduction automatique et la formation des traducteurs : réflexions sur le statu quo et perspectives - En raison principalement de pressions budgétaires, un grand nombre des besoins de traduction des communautés de langue officielle 
en situation minoritaire au Canada reste à combler. L'utilisation de la traduction automatique pourrait représenter une solution rentable, mais seulement si les membres de cette communauté acceptent cette forme de traduction. Le présent article fait état d'une expérience au cours de laquelle des membres d'une des communautés de langue officielle en situation minoritaire - en l'occurrence les Fransaskois - ont répondu à un sondage visant à mesurer leur opinion de la traduction automatique. Les résultats montrent que, bien que beaucoup de Fransaskois soient réceptifs à l'utilisation de traductions automatiques révisées, les professionnels de la langue s'opposent fermement à l'utilisation de traductions automatiques, sous quelque forme que ce soit. Ce constat porte à se demander si la formation des traducteurs à l'utilisation des outils informatiques pourrait être un facteur sousjacent à cette réaction à l'utilisation de la traduction automatique, ce qui, en revanche, nous porte à proposer une nouvelle approche visant à mieux intégrer la technologie aux programmes de formation de traducteurs.

Keywords: machine translation, official language minority communities, Fransaskois, translator training, CERTT project

Mots clés : traduction automatique, communautés de langue officielle en situation minoritaire, Fransaskois, formation de traducteurs, projet CERTT

\section{Lynne Bowker}

School of Translation and Interpretation

University of Ottawa

70, Laurier Ave. East

Ottawa, Ontario K1N 6N5

lbowker@uottawa.ca 